
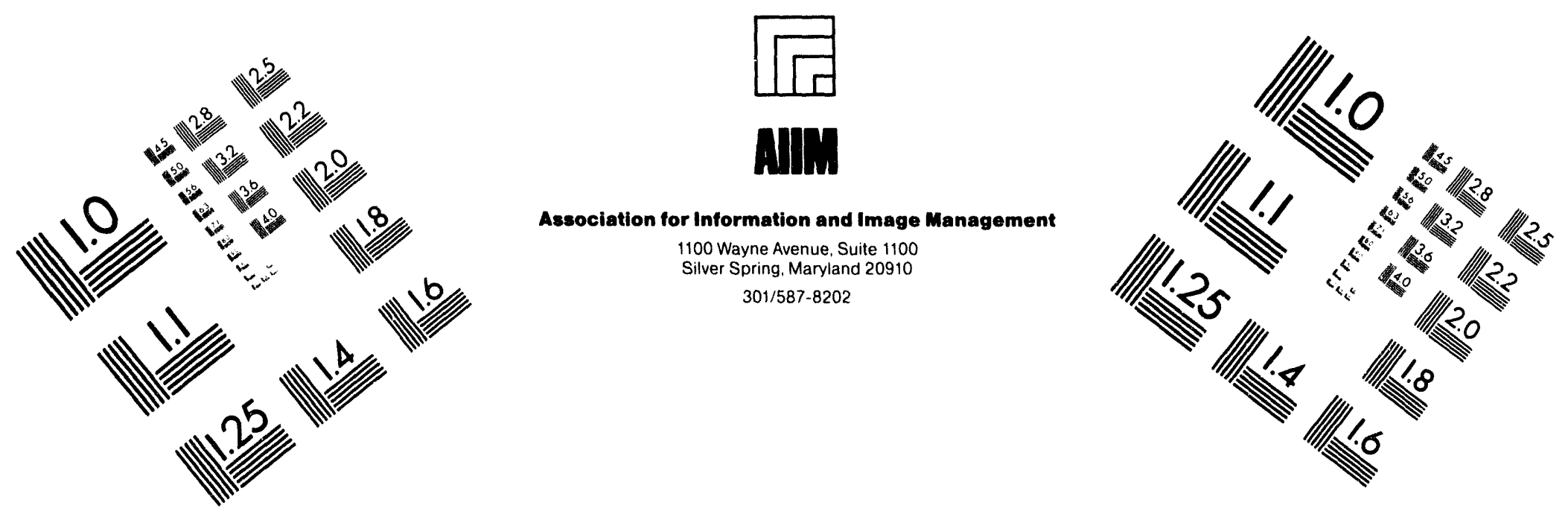

\title{
Centimeter
}

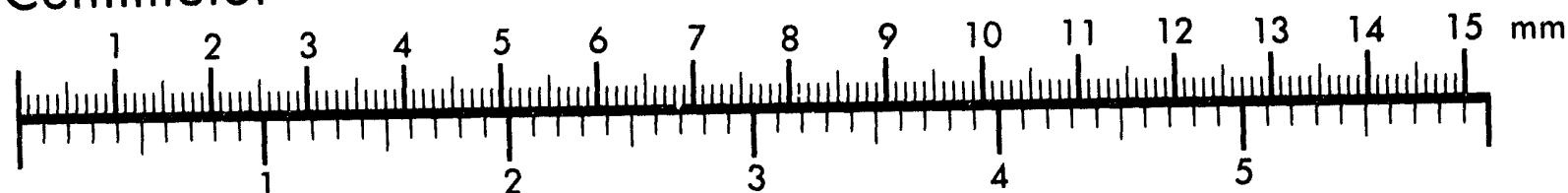

Inches
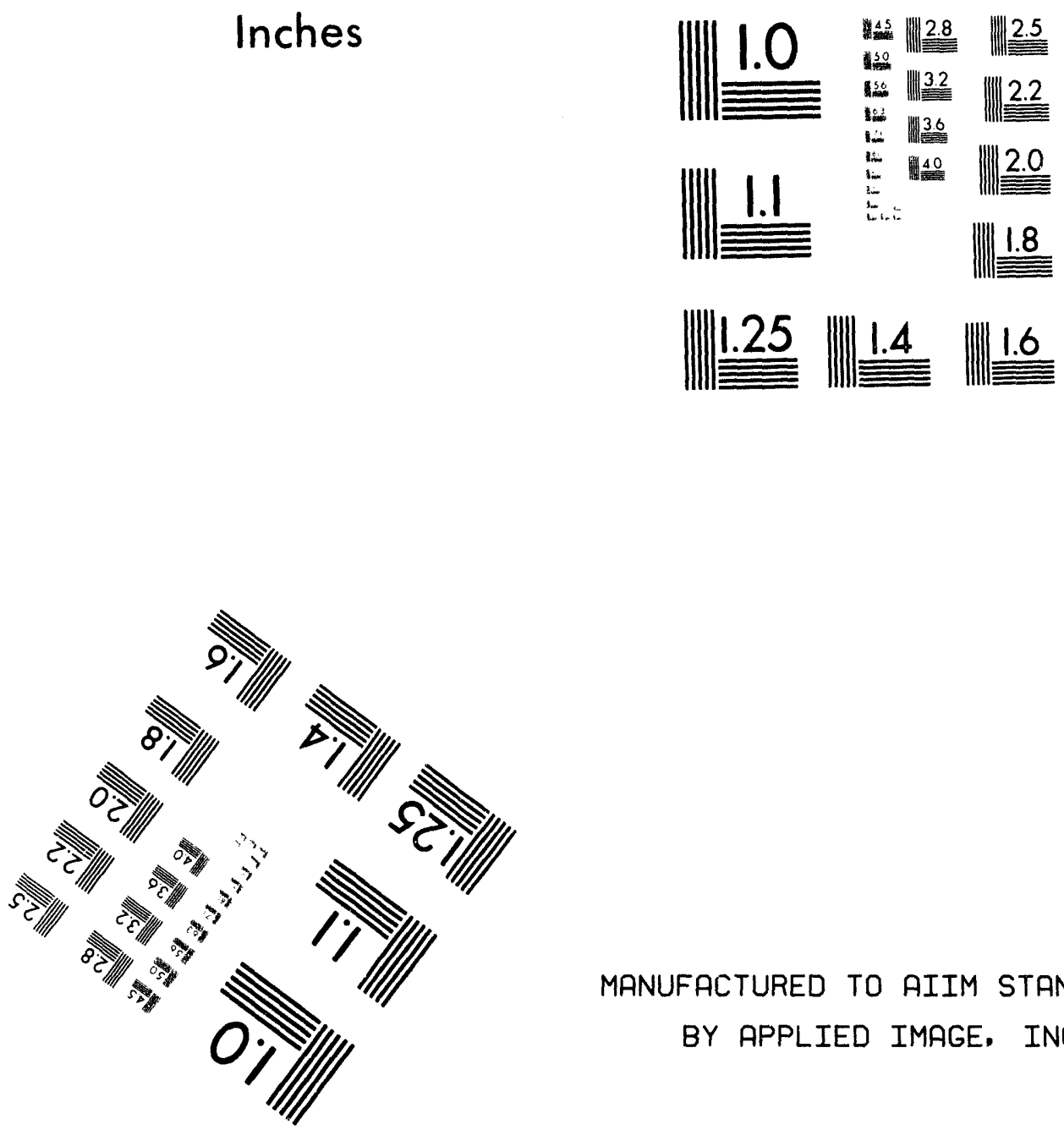

MANUFACTURED TO AIIM STANDARDS

BY APPLIED IMAGE, INC.

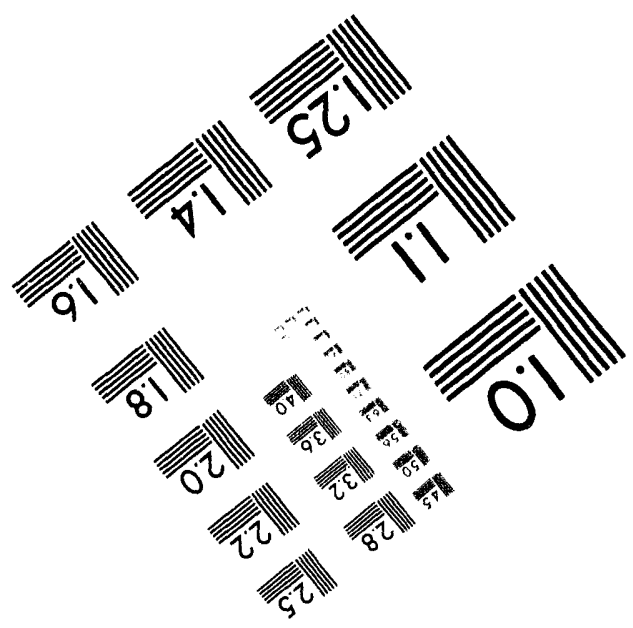



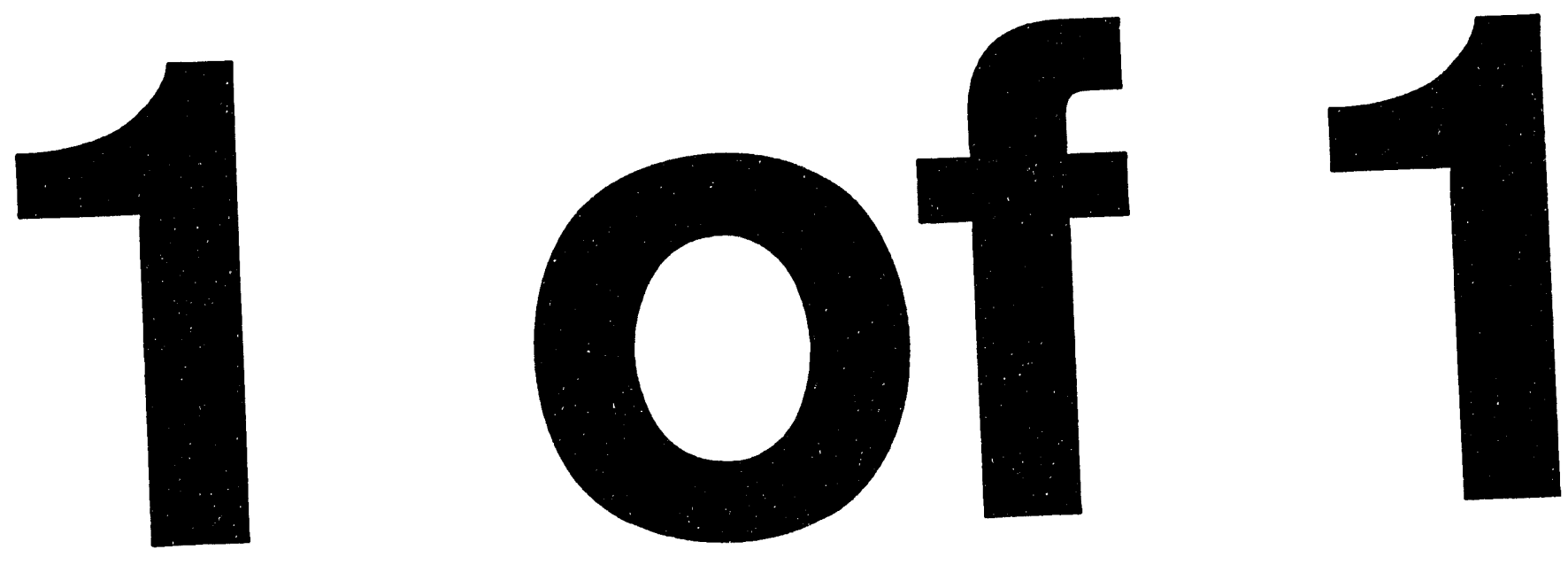


\title{
Transient Failure Behavior of HT9
}

\author{
DISCLAIMER
}

This report was prepared as an account of work sponsored by an agency of the United States Government. Neither the United States Government nor any agency thereof, nor any of their employees, makes any warranty, express or implied, or assumes any legal liability or responsibility for the accuracy, completeness, or usefulness of any information, apparatus, product, or process disclosed, or represents that its use would not infringe privately owned rights. Reference herein to any specific commercial product, process, or service by trade name, trademark, manufacturer, or otherwise does not necessarily constitute or imply its endorsement, recommendation, or favoring by the United States Government or any agency thereof. The views and opinions of authors expressed herein do not necessarily state or reflect those of the United States Government or any agency thereof.

Prepared for the U.S. Department of Energy

Office of Environmental Restoration and

Waste Management

(2) Westinghouse Hanford Company Richland, Washington

Hanford Operations and Engineering Contractor for the

U.S. Department of Energy under Contract DE-ACO6-87RL.10930

Copyright License By acceptence of this article, the publisher and/or recipient acknowledges the
U.S. Government's right to retain a nonexclusive, royaty-free license in and to eny copyright covering this paper.

DISTRIBUTION OF THIS DOCUMENT IS UNLIMITED

Approved for Public Release

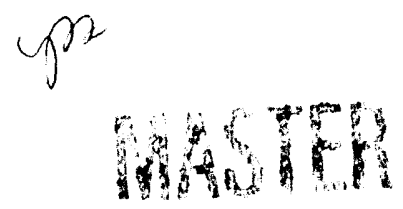




\section{Transient Failure Behavior of HT9}

F. H. Huang

Date Published

July 1994

Prepared for the U.S. Department of Energy

Office of Environmental Restoration and Waste Management

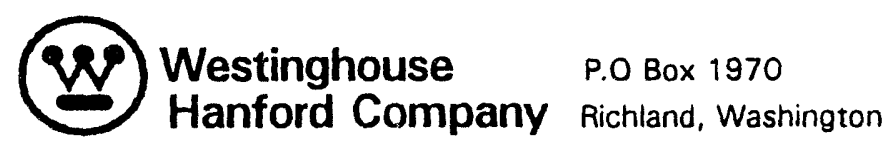

Hanford Operations and Engineering Contractor for the

U.S. Department of Energy under Contract DE-ACOL-37RL10930

Copyright Licanse By acceptance of this article, the publisher and/or rocipient acknowindges the

U.S. Government's right to retain a nonexclusive, royalty-free license in and to any copyright covering this paper 
LEGAL DISCLAIMER

This report was prepared as an account of work sponsored by an agency of the United States Government. Neither the United States Government nor any agency thereof, nor any of their employees, nor any of their contractors, subcontractors or their employees, makes any warranty, express or implied, or assumes any legal liability or responsibility for the accuracy, completeness, or any third party's use or the results of such use of any information, apparatus, product, or process disclosed, or represents that its use would not infringe privately owned rights. Reference herein to any specific commercial product, process, or service by trade name, trademark, manufacturer, or otherwise, does not necessarily constitute or imply its endorsement, recommendation, or favoring by the United States Government or any agency thereof or its contractors or subcontractors. The views and opinions of authors expressed herein do not necessarily state or reflect those of the United States Government or any agency thereof.

This report has been reproduced from the best available copy.

Printed in the United States of America

DISCLM-2.CHP (1-91) 
WHC-SA-2513-FP

TRANSIENT FAILURE BEHAVIOR OF HT9

\begin{abstract}
Alloy HTg has been chosen as candidate materials for fast and fusion reactor applications because the material exhibits excellent resistance to void swelling. However, ferritic alloys are known to undergo a ductilebrittle transition as the test temperature is decreased. This inherent problem has limited their applications to reactor component materials subjected to low neutron exposures. Despite the ductile-brittle transition problem, results show that the materials exhibit superior resistance to fracture under very high neutron fluences at irradiation temperatures above $380^{\circ} \mathrm{C}$. Results also show that the transient behavior for HTg cladding specimens taken from the fuel column region and cladding taken from outside the fuel column or unirradiated cladding are the same. HTg cladding maintained its transient strength with irradiation to a fluence of $9 \times 10^{22}$ $\mathrm{n} / \mathrm{cm}^{2}(\mathrm{E}>0.1 \mathrm{MeV})$.
\end{abstract}

\title{
1.0 INTRODUCTION
}

Fuel pellets are filled in long cylindrical cladding tubes in a nuclear reactor. These tubes are very thin with a thickness of $0.35 \mathrm{~mm}$ and an inner diameter of 4 to $5 \mathrm{~mm}$. They are constantly subjected to severe mechanical loads and thermal environments during normal operation of reactors or transient heating conditions in off-normal events. The cladding will deform by the internal pressure at elevated temperatures, the expanding fuel pellets, and the rapid rise of temperature in loss-of-flow (LOF) and transient overpower (TOP) events. As a consequence, the mechanical properties of the irradiated cladding will be altered under these circumstances. Understanding the mechanical behavior of fuel cladding for a wide range of temperature and stress states is thus essential for the reliable prediction of fuel pin performance during normal operation and off-normal situations.

It is desirable to measure the postirradiation fracture resistance of fuel cladding for reactor safety analysis. However, because the tube wall thickness is only $0.35 \mathrm{~mm}$, fracture toughness test techniques on such a thin and curved structure have not yet been developed. Alternatively, experimental results have shown that the cladding failure behavior at a constant temperature can be characterized by "stress" and "rupture time" reasonably well, while parameters such as "stress" and "failure temperature" suitably describe the tube life of cladding pin subjected to off-normal transient conditions. In the following sections, stress rupture testing performed at a constant temperature and fuel cladding transient testing (FCTT) at a constant temperature ramp rate are discussed. 


\subsection{STRESS RUPTURE TESTING}

Postirradiation stress rupture tests were first performed on $20 \% \mathrm{CW} 316$ SS cladding specimens irradiated in the EBR-II to fluences of 5.1 and $9.1 \mathrm{x}$ $10^{22} \mathrm{n} / \mathrm{cm}^{2}$ (E $>0.1 \mathrm{MeV}$ ) at $649^{\circ} \mathrm{C}$. This early work was conducted to investigate the effect of neutron irradiation on the cladding rupture life of the material used in the FFTF first core. Results showed that average rupture lives were reduced by a factor of 20 to 30 over the unirradiated values. The cladding rupture testing proved to be effective for material development and useful to reactor design and safety analysis.

The in-reactor rupture strength of HT9 was evaluated by performing stress rupture tests on tubing samples. Specimens $22 \mathrm{~mm}$ long were cut from cladding with $4.6 \mathrm{~mm}$ outside diameter (OD) by $4.2 \mathrm{~mm}$ inside diameter (ID). Other specimens with a length of $28 \mathrm{~mm}$ were cut from cladding having $5.8 \mathrm{~mm}$ OD by $5.1 \mathrm{~mm}$ ID. The tube specimens were pressurized and welded by electron beam welding, not the standard TIG welds. Argon was filled in the specimens as the pressurizing medium and cover gas. They were soaked in furnaces at various temperatures. The stress rupture times were determined when the specimen failed. Earlier stress rupture data from irradiations in the EBR-II were obtained from $5.84 \mathrm{~mm}$ (OD) by $5.08 \mathrm{~mm}$ (ID) cladding fabricated from HT9 (Heat No. 91353). The failure time, hoop stress, and nominal and maximum diametral strains are given in Table 1.

The FFTF MOTA experiment contained rupture specimens fabricated from three ferritic alloys: HT9 heats 91353 and 84425 , and $9 \mathrm{Cr}-1 \mathrm{MO}$. The HT9 stress rupture data exhibit rupture times similar to those determined from thermal testing (Figure 1). The same MOTA experiment had rupture specimens of $20 \% \mathrm{CW}$ 316 SS irradiated to a peak fluence of $14 \times 10^{22} \mathrm{n} / \mathrm{cm}^{2}$. The rupture times of irradiated specimens of $20 \%$ CW 316 SS were found again to be shorter than those of unirradiated specimens.

Table 1 Stress rupture data for HTg irradiated in the EBR-II

\begin{tabular}{|c|c|c|c|c|c|}
\hline $\begin{array}{l}\text { Temp. } \\
\text { ( } \mathrm{C} \text { C) }\end{array}$ & $\begin{array}{l}\text { Hoop stress } \\
(\mathrm{MPa})\end{array}$ & $\begin{array}{r}\text { Fluence } \\
\left(\times 10^{22} \mathrm{n} / \mathrm{cm}^{2}\right)\end{array}$ & $\begin{array}{l}\text { Time } \\
(\mathrm{Hr})\end{array}$ & $\begin{array}{c}(\Delta D) / 0 \\
(\%)\end{array}$ & $\begin{array}{c}(\Delta)_{0} / D_{\max } \\
(\%)\end{array}$ \\
\hline 593 & $\begin{array}{l}170 \\
187 \\
215\end{array}$ & $\begin{array}{l}1.18 \\
1.10 \\
0.153\end{array}$ & $\begin{array}{r}1879 \\
1750 \\
243\end{array}$ & $\begin{array}{l}3.9 \\
2.8 \\
3.8\end{array}$ & $\begin{array}{l}9.6 \\
4.4 \\
8.7\end{array}$ \\
\hline 650 & $\begin{array}{l}75 \\
80 \\
90\end{array}$ & $\begin{array}{l}1.81 \\
1.07 \\
0.387\end{array}$ & $\begin{array}{r}2873 \\
1694 \\
615\end{array}$ & $\begin{array}{l}3.4 \\
3.7 \\
2.1\end{array}$ & $\begin{array}{l}6.5 \\
8.3 \\
6.5\end{array}$ \\
\hline 704 & $\begin{array}{l}34 \\
38 \\
48\end{array}$ & $\begin{array}{l}0.354 \\
0.284 \\
0.166\end{array}$ & $\begin{array}{l}563 \\
450 \\
264\end{array}$ & $\begin{array}{r}20.7 \\
12.1 \\
4.9\end{array}$ & $\begin{array}{l}39.0 \\
35.0 \\
23.0\end{array}$ \\
\hline
\end{tabular}




\subsection{FUEL CLADDING TRANSIENT TESTING}

A detailed knowledge of fuel cladding behavior during reactor transients is required for core design and the safety analysis of both LOF and TOP events. The FCTT system was developed to simulate reactor transient heating and loading conditions in the laboratory [2]. Transient test equipment and procedures were developed for both unirradiated and irradiated cladding. The data obtained from simulated transients are useful for understanding the changes in mechanical properties of the irradiated cladding during an actual overpower transient. These cladding properties are necessary for analysis of

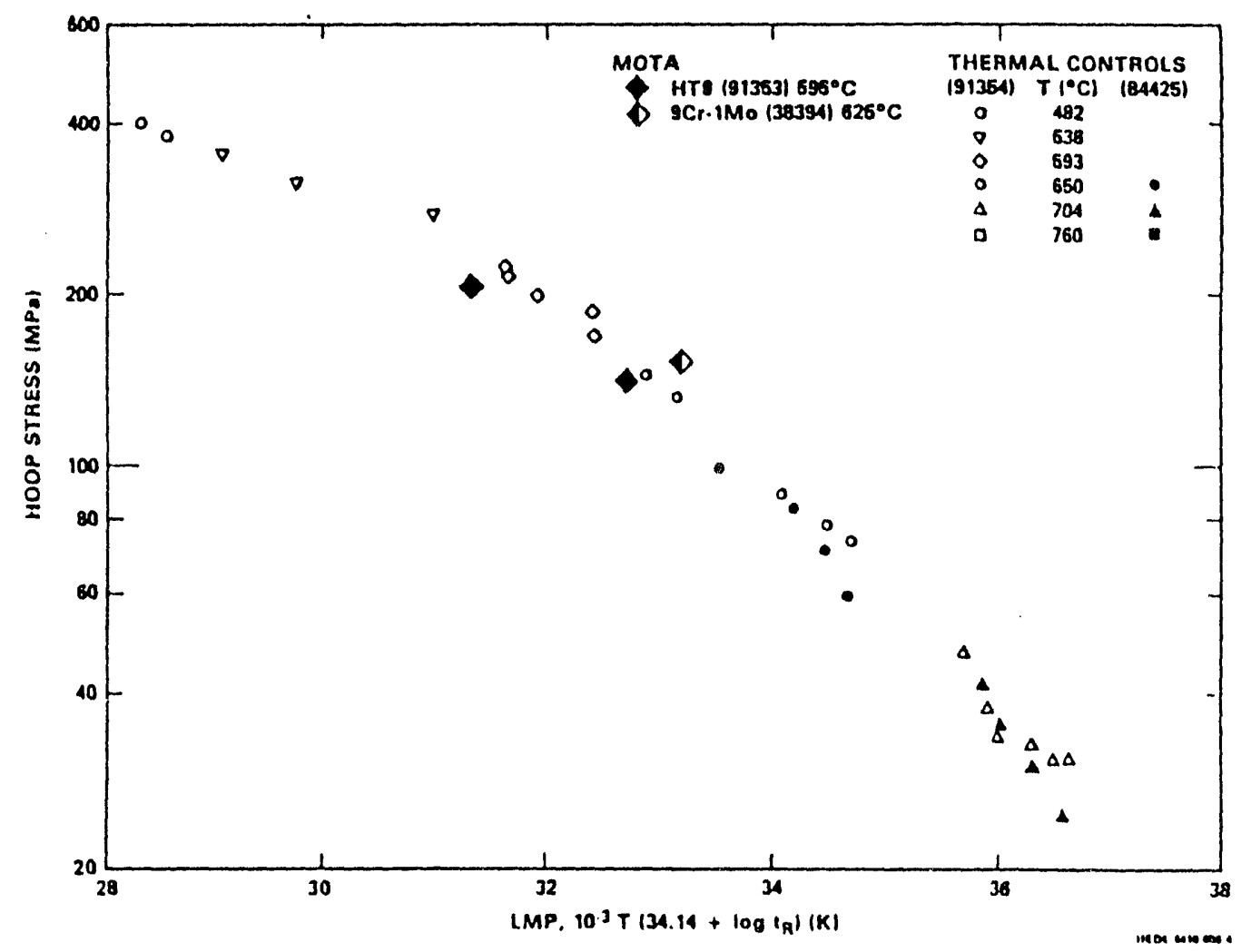

Figure 1 Stress rupture data for HTg and $9 \mathrm{Cr}$-1Mo [1].

design base transients, for determination of post-transient operation performance and cumulative damage rules, and for definition of fuel pin integrity limits.

\subsection{Experimental Procedures}

Simulated transient tests were conducted by using the FCTT system to heat the pressurized cladding sample at a fixed rate until rupture occurred. The specimen was heated to a predetermined temperature with closed-10op induction 
power control and the feedback thermocouple spot welded onto the specimen An extensometer was used to monitor the diameter of the specimen during the test. Specimens were tested at heating rates of $0.56,5.6$, and $110^{\circ} \mathrm{C} / \mathrm{sec}$ with different induction coils. The heats of HTg used to fabricate material specimens for EBR-II and FFTF experiments and for fuel pin experiments along with the vendors are listed in Tables 2 and 3 , respectively.

Table 2 HTg Heats Used for Mechanical Properties Experiments.

\begin{tabular}{lll}
\hline Heat & \multicolumn{1}{c}{ Vendor } & Experiment \\
\hline 91353 Bar & $\begin{array}{l}\text { Carpenter Technology } \\
\text { Carpenter Technology }\end{array}$ & $\begin{array}{l}\text { AAXV, MOTA } \\
\text { AAXV }\end{array}$ \\
91353 Duct & $\begin{array}{l}\text { Carpenter Technology } \\
\text { Superior Tube Company }\end{array}$ & AAXV, MOTA \\
91354 Bar & Carpenter Technology & MOTA \\
91354 Tubing & Combustion Engineering AAXV, MOTA \\
84425 & & \\
\hline
\end{tabular}

Table 3 HTg Heats Used for Fuel Pin Experiments.

\begin{tabular}{|c|c|c|c|c|}
\hline Heat & Vendor & Production Method & $\begin{array}{r}\text { Fuel Pin } \\
\text { Experiments } \\
\end{array}$ & \\
\hline 91353 & CarTech & $\begin{array}{l}\text { Vacuum Induction Melt, } \\
\text { Electroslag Remelt }\end{array}$ & - & \\
\hline 91354 & CarTech & $\begin{array}{l}\text { Vacuum Induction Melt, } \\
\text { Electroslag Remelt }\end{array}$ & P44 & \\
\hline 84425 & CarTech & $\begin{array}{l}\text { Vacuum Induction Melt, } \\
\text { Vacuum Arc Remelt }\end{array}$ & $\begin{array}{l}\mathrm{ACO}-1, \\
\mathrm{ACO}-4,\end{array}$ & $\begin{array}{l}\mathrm{ACO}-3 \\
\mathrm{FO}-2\end{array}$ \\
\hline 92235 & CarTech & $\begin{array}{l}\text { Vacuum Induction Melt, } \\
\text { Vacuum Arc Remeit }\end{array}$ & CDE & \\
\hline CV0385 & ORNL & Vacuum Remelt of 91354 & - & \\
\hline XA3607 & $\begin{array}{l}\text { Combustion } \\
\text { Engineering }\end{array}$ & $\begin{array}{l}\text { Electroslag Remelt of } \\
\text { an Air Induction Melt }\end{array}$ & - & \\
\hline$R 74075$ & $\begin{array}{l}\text { Federal } \\
\text { Mogul }\end{array}$ & $\begin{array}{l}\text { Hot Isostatic Powder } \\
\text { Compaction at } 2050^{\circ} \mathrm{F}\end{array}$ & - & \\
\hline
\end{tabular}


Irradiated specimens were prepared from fuel pins after all fuel was removed by mechanical drilling. The specimen was first pressurized to about $80 \%$ of desired pressure at room temperature, then heated to the initial temperature. After reaching the initial pressure and temperature, the specimen was heated at a constant rate until it failed. The parameters measured are failure temperature and failure strain at the selected hoop stress which remains relatively constant throughout the test. The failure strain measurement is taken as close as possible to the failure. A cumulative damage failure correlation can be developed from these FCTT data. Failure is predicted on the basis of a cumulative damage function (CDF) in which the life fraction is calculated from the correlation.

\subsection{Transient Failure Correlation}

The failure criterion developed on the basis of standard FCTT data has been used for fuel assembly design and safety to analyze LOF events in which the temperature is assumed to increase steadily. In reality, LOF type events may give rise to relatively constant temperatures for a period of time. In this case, ramp and hold tests provide a better simulation of the transient conditions to which the fuel cladding is exposed. A general description of the correlation for FCTT and ramp/hold tests is given as follows. The temperature dependence of stress rupture life is represented in terms of the Dorn parameter, $\theta$, and the activation energy, $Q$, as follows:

$$
t_{r}=\theta \exp \left(\frac{h}{R T}\right)
$$

where $R=1.986 \mathrm{cal} / \mathrm{mole} \cdot \mathrm{K}$.

The cumulative damage fraction (CDF) is calculated by integration:

$$
\operatorname{CDF}=\int_{0}^{t} \frac{d t}{t_{r}(\sigma, T)}
$$

Since damage is accumulated in the cladding whether the temperature is ramped or held constant, the calculated CDF value should reflect the entire temperature history encountered:

$$
\operatorname{CDF}=\int_{0}^{t} \frac{d t}{t_{r}}+\sum_{0}^{t_{i}} \frac{t}{t_{r}}
$$


where the first term reflects the damage accumulated during temperature ramps, and the second term reflects the damage accumulated at constant temperature. For the ramp and hold test, where the initial temperature is $T_{i}$, the heating rate is $d T / d t$, the hold temperature is $T_{H}$, and the hold time is $t_{H}$, Equation (3) becomes

$$
\operatorname{CDF}=\int_{T_{i}}^{T_{H}} \frac{d T}{\dot{T} \theta \exp \left(\frac{0}{R T}\right)}+\frac{t_{H}}{\theta \exp \left(\frac{\theta}{R T_{H}}\right)}
$$

The first term in Equation (4) was computed previously [3] using the approximation

$$
\int_{T_{j}}^{T_{H}} \frac{d T}{\exp \left(\frac{Q}{R T}\right)} \sim \frac{R T_{H}^{2}}{Q} \exp \left(\frac{-Q}{R T_{H}}\right)
$$

and thus

$$
\operatorname{CDF}=\frac{1}{\theta}\left(\frac{R T_{H}^{2}}{\dot{T}_{Q}}+t_{H}\right) \exp \left(\frac{-Q}{R T_{H}}\right) .
$$

The Dorn parameter was calculated for ramp and hold tests using Equation 5 and assuming the validity of the life fraction rule, which predicts that failure will occur when the CDF is equal to 1 :

$$
\theta=\left(\frac{R T_{H}^{2}}{\dot{T}_{Q}}+t_{H}\right) \exp \left(\frac{-Q}{R T_{H}}\right) .
$$

For standard FCTT tests, the hold time $t_{H}$ is zero, and $T_{H}=T_{f}$, where $T_{f}$ is the failure temperature. The Dorn parameter is therefore expressed by

$$
\theta=\left(\frac{R T_{f}^{2}}{T_{Q}}\right) \exp \left(\frac{-Q}{R T_{f}}\right)
$$

The relationship between the Dorn parameter and stress is often described for transient data by an expression of the form 


$$
\ln \theta=A+B \ln \left[\ln \left(\frac{\sigma^{*}}{\sigma}\right)\right]
$$

where $\sigma^{*}$ is the hardness of the material. The constants $A$ and $B$ can be determined from the experimental FCTT or ramp/hold data. The appropriate value of $\theta$ can then be calculated for each given stress $\sigma$ from Equation 8. Data from the FCTT transient tests at heating rates of $0.56,5.6$, and $111^{\circ} \mathrm{C} / \mathrm{s}$ were used to develop the correlation for HTg cladding (Figure 2). The

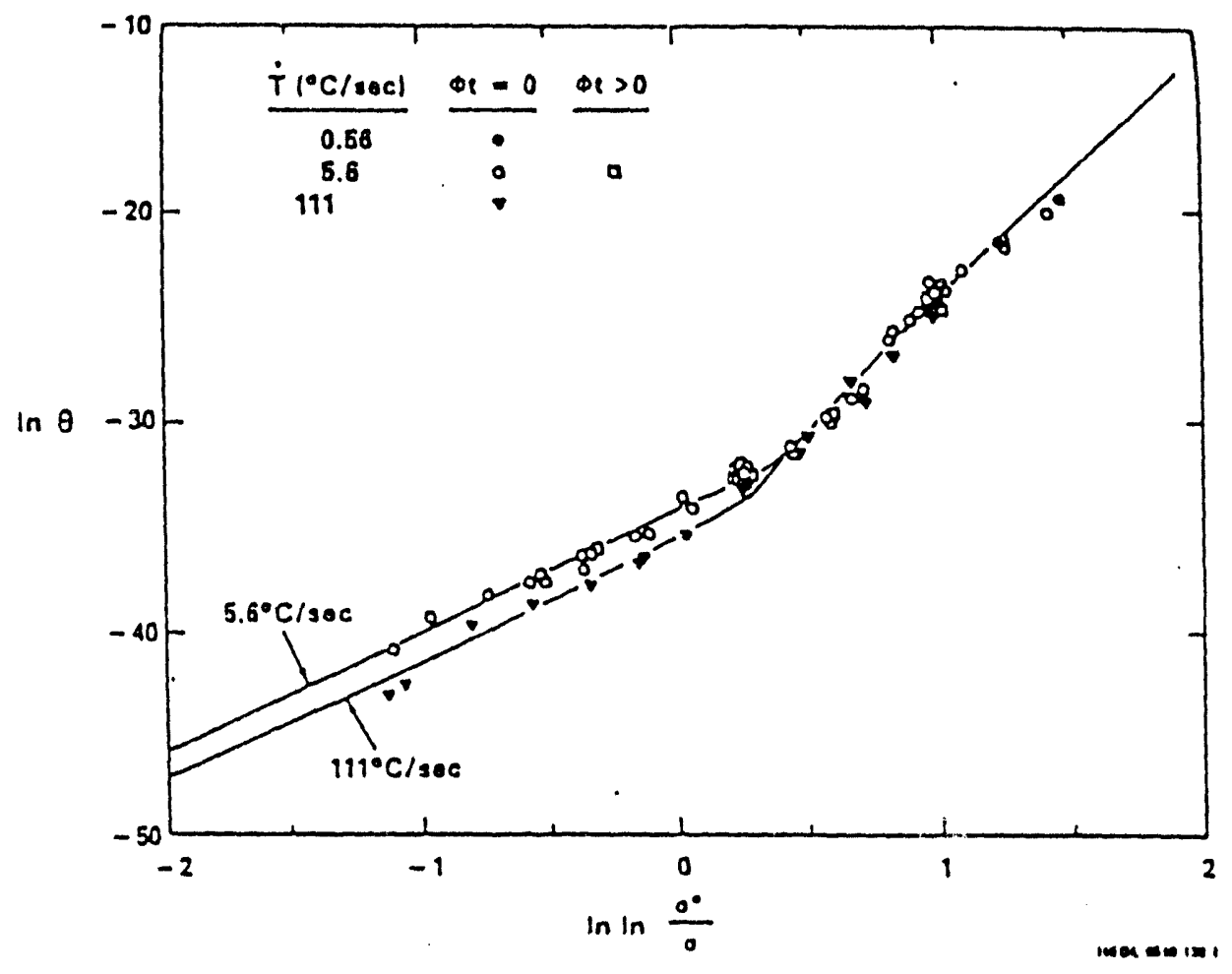

Figure 2 CDF correlation for the transient test on HTg cladding.

results were fit to Equation 8 to determine constants $A$ and $B$. A was found to depend on hoop stress and heating rate, while $B$ was dependent of stress only. For a given stress, the value of $\theta$ is obtained from Equation 8 and the failure temperature is calculated from Equation 7 . The stress versus failure temperature trend curves for unirradiated HTg cladding are shown in Figure 3. 


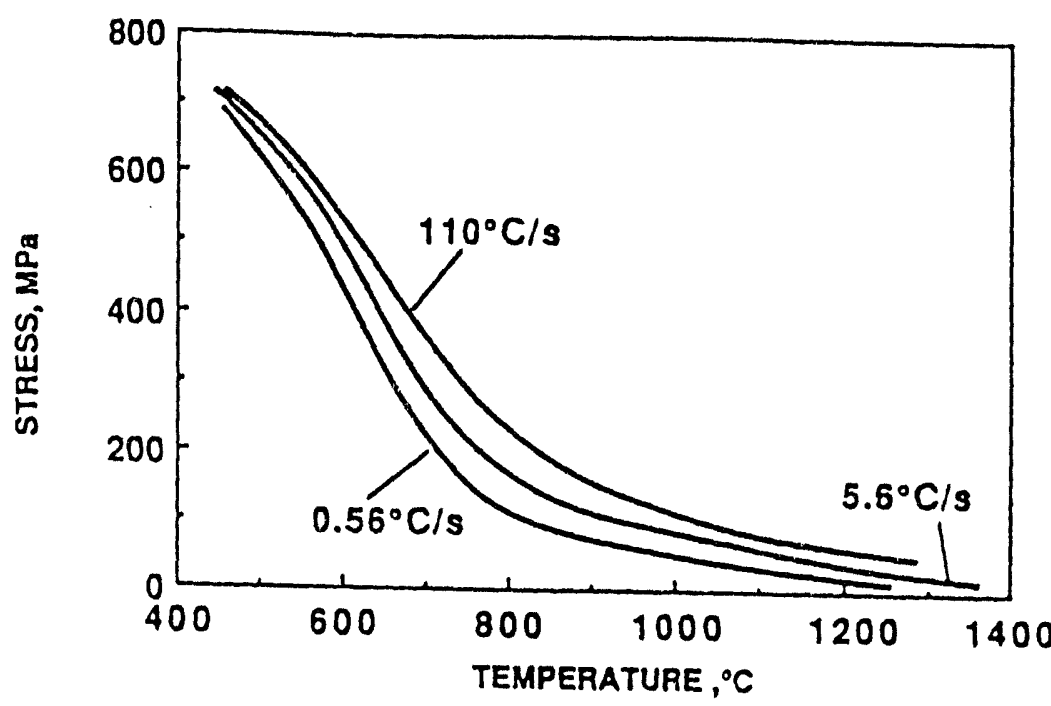

Figure 3 Stress versus failure temperature trend curves for unirradiated HTS cladding [4].

\subsection{Ramp and Hold Failure Correlation.}

All specimens were initially heated from $370^{\circ} \mathrm{C}$ at $5.6^{\circ} \mathrm{C} / \mathrm{s}$ until a preselected hold temperature was reached. Results showed that the measured failure times did not consistently agree with those predicted using the life fraction approach, with either the existing FCTT failure correlation or with the stress rupture correlation for unirradiated cladding. Each correlation did a reasonab? a job over only a portion of the temperature range of interest. A new correlation was therefore required to describe the ramp and hold test data adequately.

Ramp and hold test results for unirradiated HTg cladding are given in Table 4. The values of $\ln \theta$ were calculated from Equation 6 for all hold temperatures with a $Q$ of $70,170 \mathrm{cal} / \mathrm{mole}$, hold temperature, hold time, and heat rate 1 isted in Table 2. In Figure 4, the values of $\ln \theta$ are plotted as a function of in [ In $\left.\left(\sigma^{*} / \sigma\right)\right]$, where $\sigma^{*}=730 \mathrm{MPa}$. As shown in the figure, the data at each hold temperature appear to be 1 inear, and all of the constant temperature 1 ines are parallel. The data for all hold temperatures ranging from 500 to $1050^{\circ} \mathrm{C}$ were fitted in Equation 8 to determine the constants $A$ and $B$ for each hold temperature. The value of $B$ was determined first to be about the same for all the hold temperature lines $(B=12.47)$. The values of $A$ were then obtained by a least squares fit to the data with Equation 8 . Figure 5 shows the temperature dependence of $A$, which can be described by the following equations: 
Table 4 Ramp and hold data on unirradiated HTg cladding. Heating rate $=5.6^{\circ} \mathrm{C} / \mathrm{sec}$.

\begin{tabular}{rrrc}
\hline $\begin{array}{l}\text { Stress } \\
(\mathrm{MPa})\end{array}$ & $\begin{array}{c}\text { Hold } \\
\text { temp. }\left({ }^{\circ} \mathrm{C}\right)\end{array}$ & $\begin{array}{c}\text { Hold time } \\
\text { to failure }(\mathrm{s})\end{array}$ & $\begin{array}{c}\text { Post-test } \\
\text { Maximum } \\
\text { strain(\%) }\end{array}$ \\
\hline & & & \\
517.7 & 500 & 1860 & 3.6 \\
541.5 & 500 & 1418 & 3.1 \\
486.7 & 500 & 15180 & 5.7 \\
505.5 & 500 & 8820 & 4.0 \\
315.7 & 600 & 653 & 5.6 \\
364.4 & 600 & 123 & 4.5 \\
260.4 & 600 & 9800 & 8.5 \\
39.5 & 1050 & 56 & 41.5 \\
24.7 & 1050 & 523 & 34.6 \\
18.8 & 1050 & 1110 & 24.7 \\
\hline
\end{tabular}

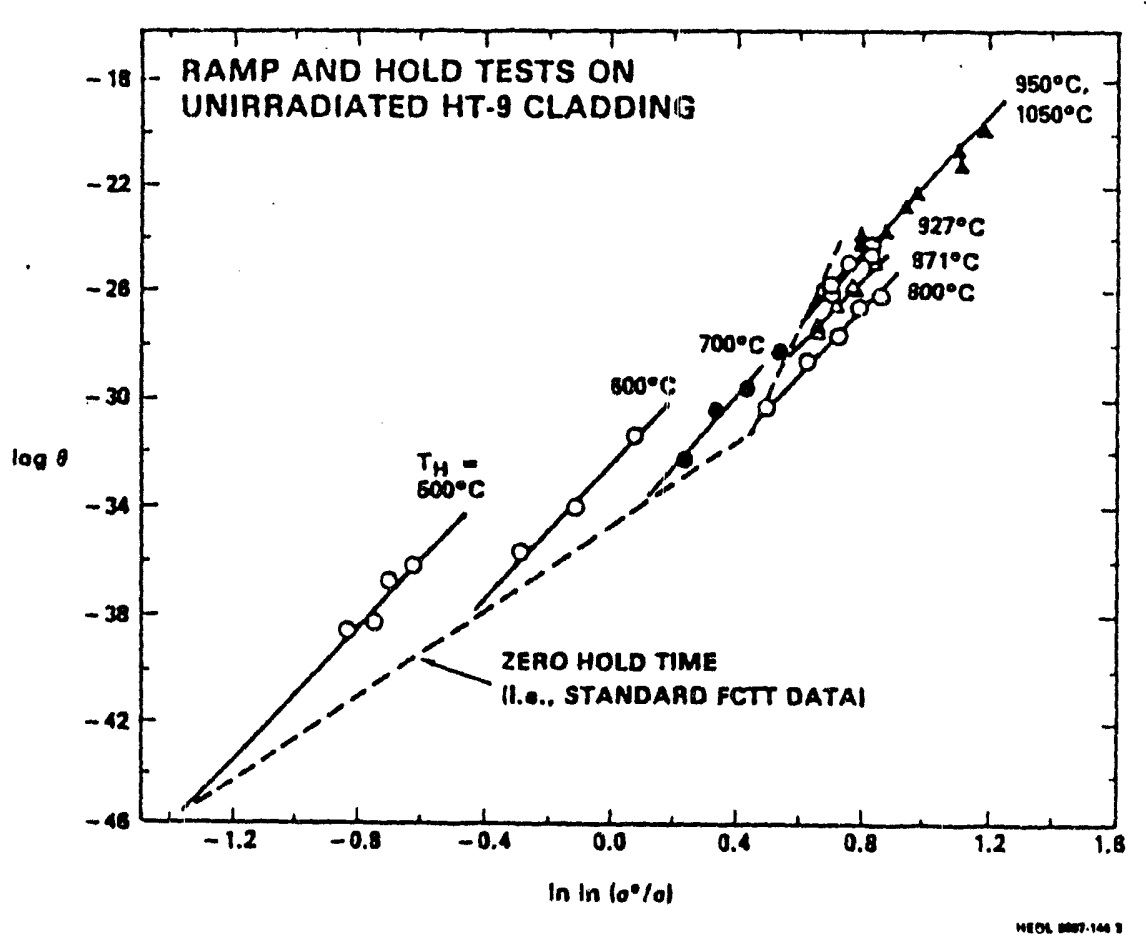

Figure 4 Stress dependence of Dorn parameter for various hold temperatures. 


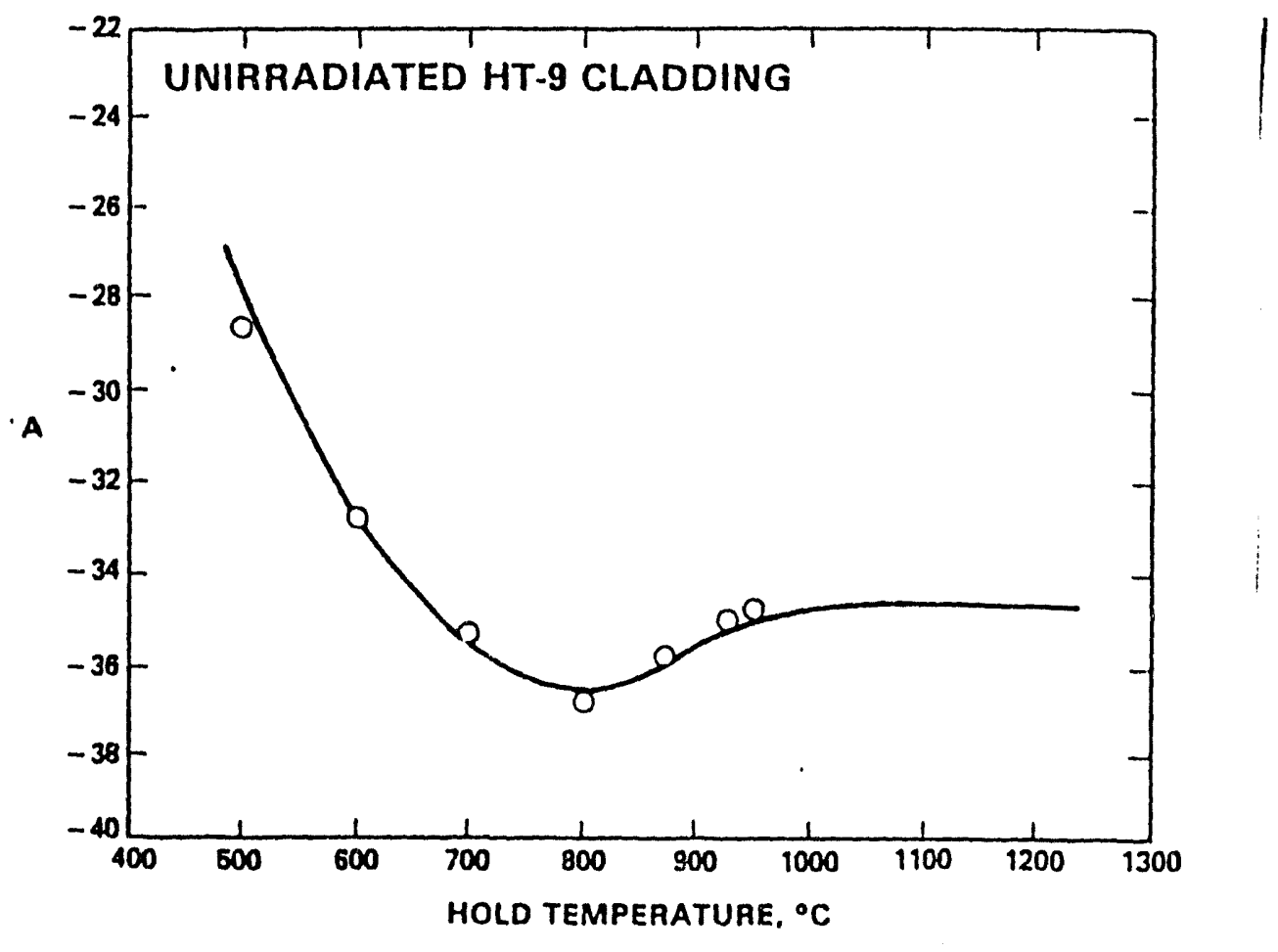

MEOL Mor.14.1

Figure 5 Value of constant $A$ as a function of hold temperature.

$A=24.942-0.153 T_{H}+9.488 \times 10^{-5} T_{H}^{2} \quad T_{H}<871^{\circ} \mathrm{C}$

$$
A=-36.1+1.5 \tanh \left[\left(T_{H}-871\right) / 80\right] \quad 871^{\circ} \mathrm{C}<T_{H}<1050{ }^{\circ} \mathrm{C}
$$

where $T_{H}$ is the hold temperature in degrees centigrade. The value of $A$ is assumed to saturate for hold temperatures above $1050^{\circ} \mathrm{C}$.

The time to failure at a constant temperature for a given stress can now be predicted from Equations 6,8 , and 9 . Hold time versus stress data are compared to the predicted values (solid lines) in Figure 6 . The data and the predictions of the equations are in good agreement. A better fit of the $A$ values in terms of $T_{4}$ would result in even better agreement between predictions of hold time and the experimental data. 

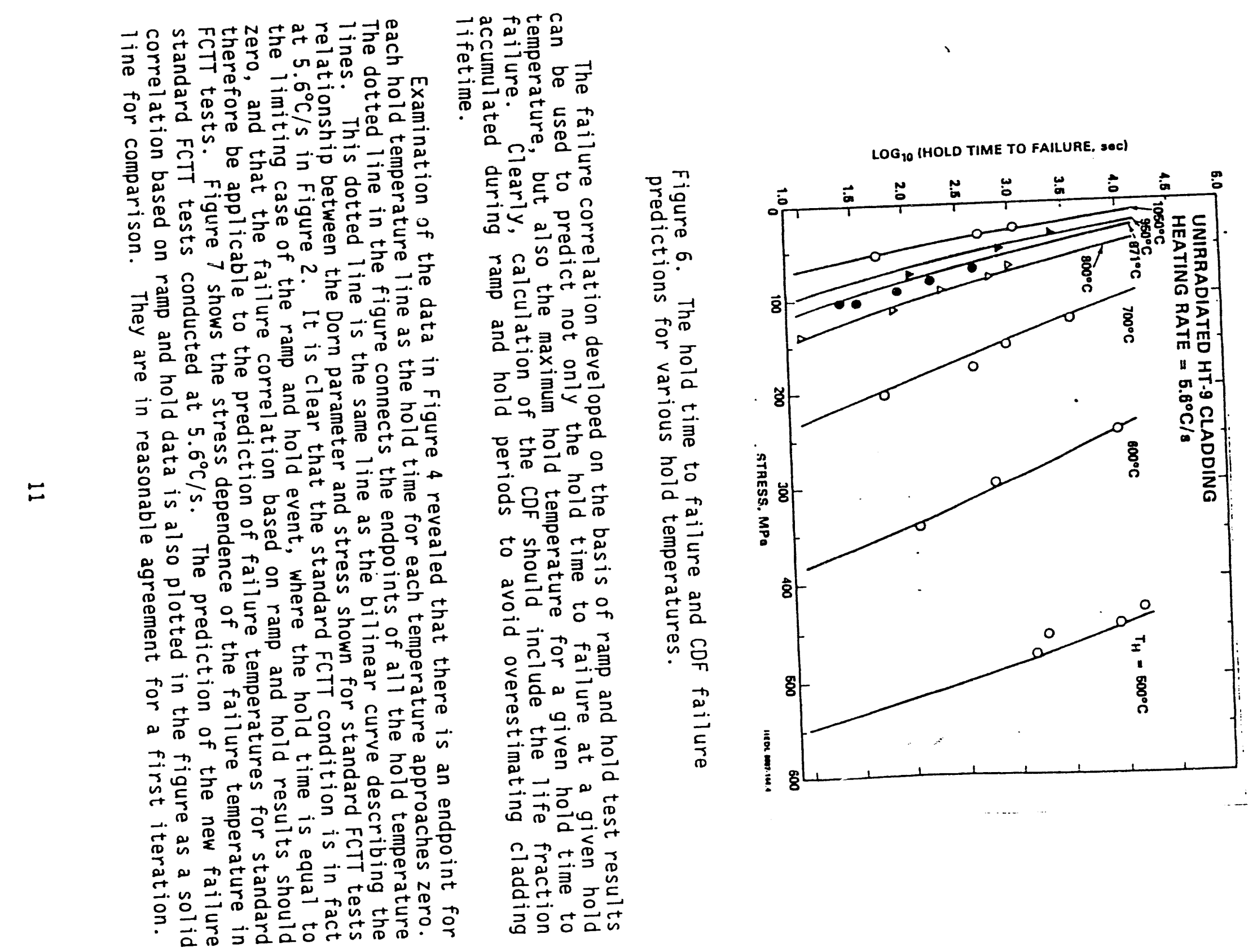


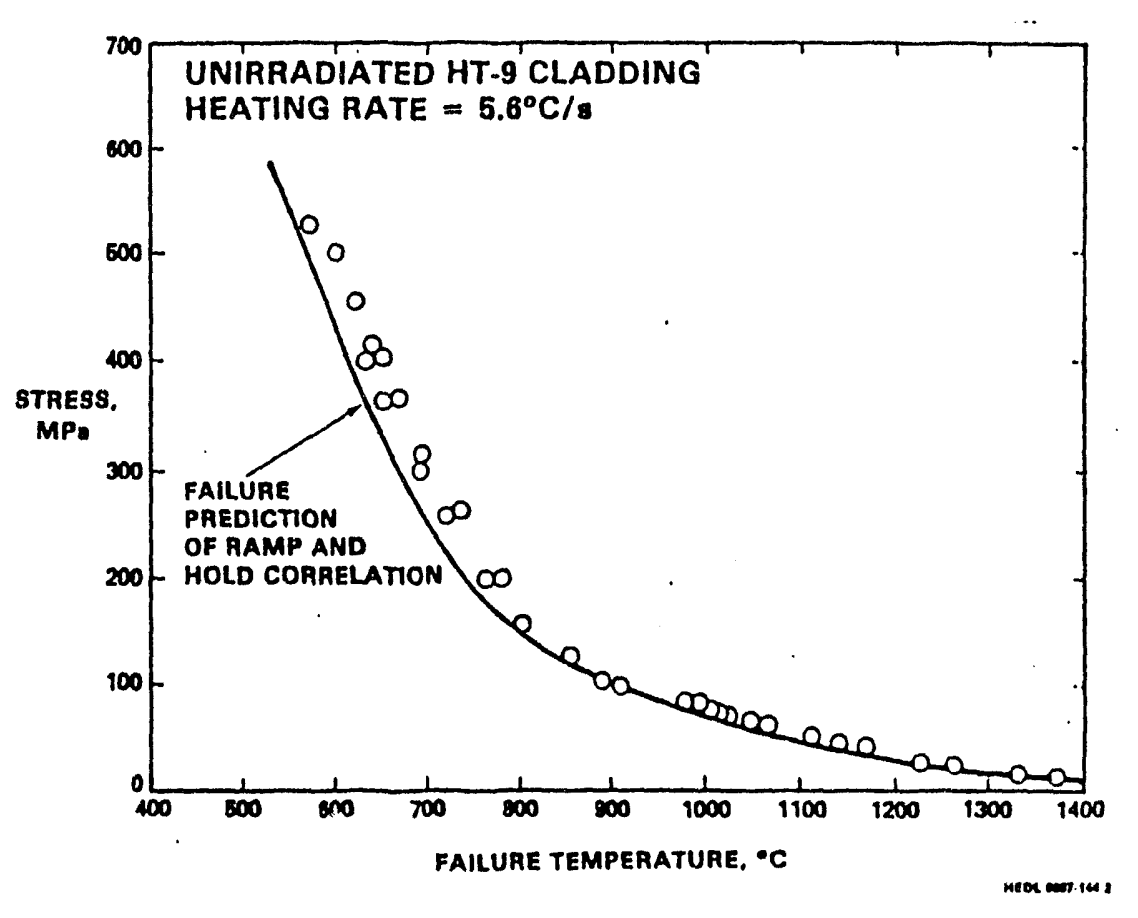

Figure 7 FCTT control data and failure correlation based on ramp and hold data.

Although analysis of ramp and hold tests can provide the information normally obtained from standard FCTT tests, more ramp and hold tests are required in order to firmly establish the linearity of the $\ln \theta-\ln \ln \left(\sigma^{*} / \sigma\right)$ lines at multiple nold temperatures. Generally, if hold time data are of interest, ramp and hold tests should be performed. A mixture of standard FCTT and ramp/hold tests should be performed to verify the failure temperature for cladding subjected to heating until failure.

\subsection{Results and Discussion}

In this section FCTT results obtained from irradiated cladding samples are presented. The tests were performed to evaluate cladding transient damage due to irradiation. Simulated transient tests were performed on HTg cladding irradiated in the P44 experiment, structural specimens in the AAXV experiment, and cladding specimens cut from ACO-1 pins. A11 P44 specimens were tested at $5.6^{\circ} \mathrm{C} / \mathrm{sec}$, the $A A X V$ specimens were tested at $111^{\circ} \mathrm{C} / \mathrm{sec}$, and the $A C O-1$ specimens were tested at the heating rates of $5.6^{\circ} \mathrm{C} / \mathrm{sec}$ and $111^{\circ} \mathrm{C} / \mathrm{sec}$. Test results for the P44 specimens are shown in Figure 8 . The behavior of unirradiated HT9 cladding is also plotted in figure 8 . As seen in this figure, the transient 


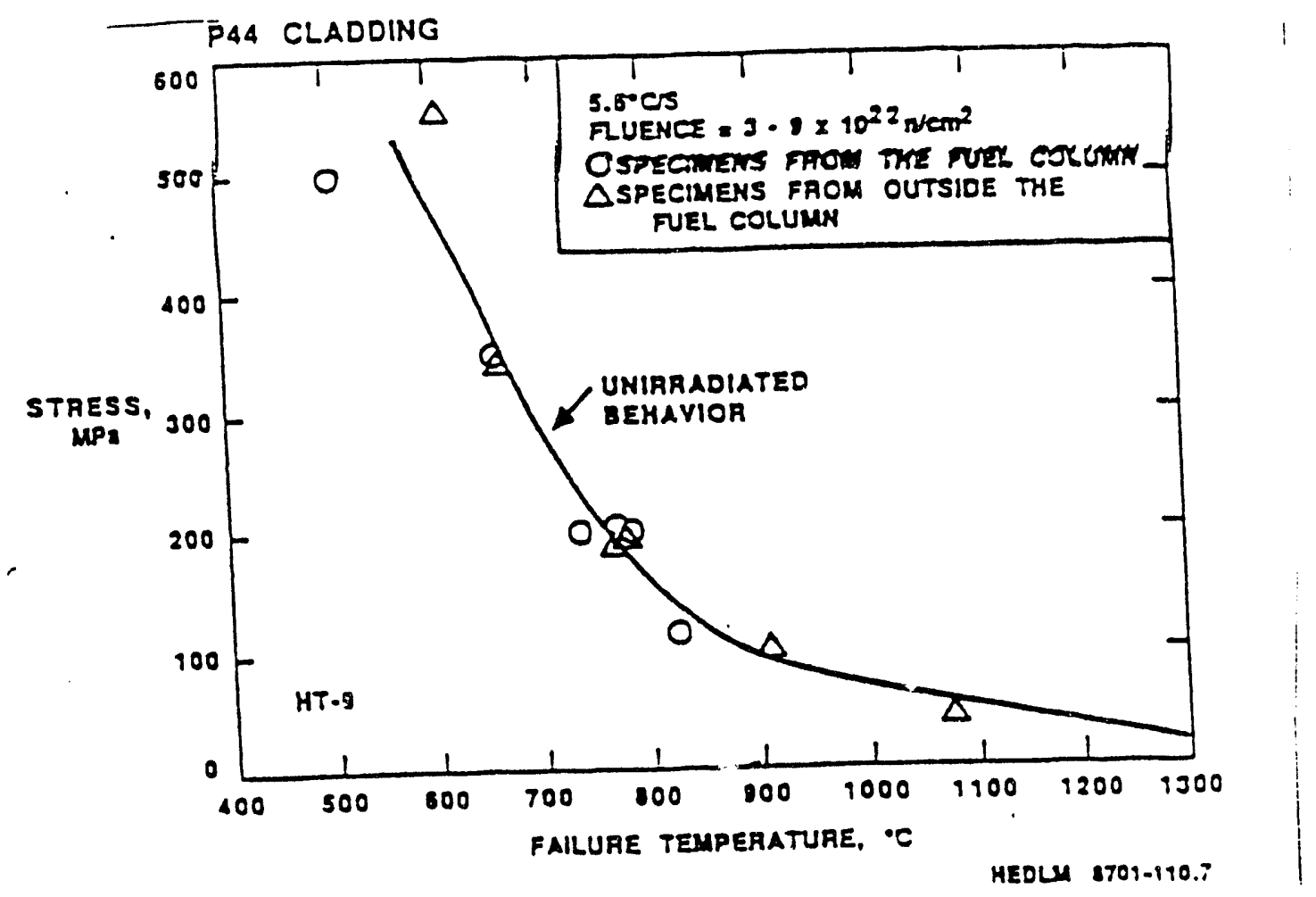

Figure 8 Failure temperature of transient tests at $5.6^{\circ} \mathrm{C} / \mathrm{sec}$ for $P 44$ specimens of HT9.

failure temperatures and stresses for HT9 cladding specimens taken from the fuel column region and cladding taken from outside the fuel column or unirradiated cladding are the same. Results al so showed that HTg cladding maintained its transient strength with irradiation to a fluence of $9 \times 10^{22} \mathrm{n} / \mathrm{cm}^{2}(\mathrm{E}>0.1 \mathrm{MeV})$. transient strength with irradiation to a fluce
The strain in terms of failure temperature is plotted in Figure 9 . Increasing
temperature inreases the strain of HTg cladding although the data scatter is large.

\subsection{CONCLUSIONS}

FCTT testing shows that the transient behavior for HTg cladding specimens taken from the fuel column region and cladding taken from outside the fuel column or unirradiated cladding are the same. HTg cladding maintained its transient strength with irradiation to a fluence of $9 \times 10^{22} \mathrm{n} / \mathrm{cm}^{2}(E>0.1 \mathrm{MeV})$.

The excellent resistance to cladding-fuel interaction and void swelling has led to choosing ferritic alloys as candidate materials for fast and fusion reactor applications. 


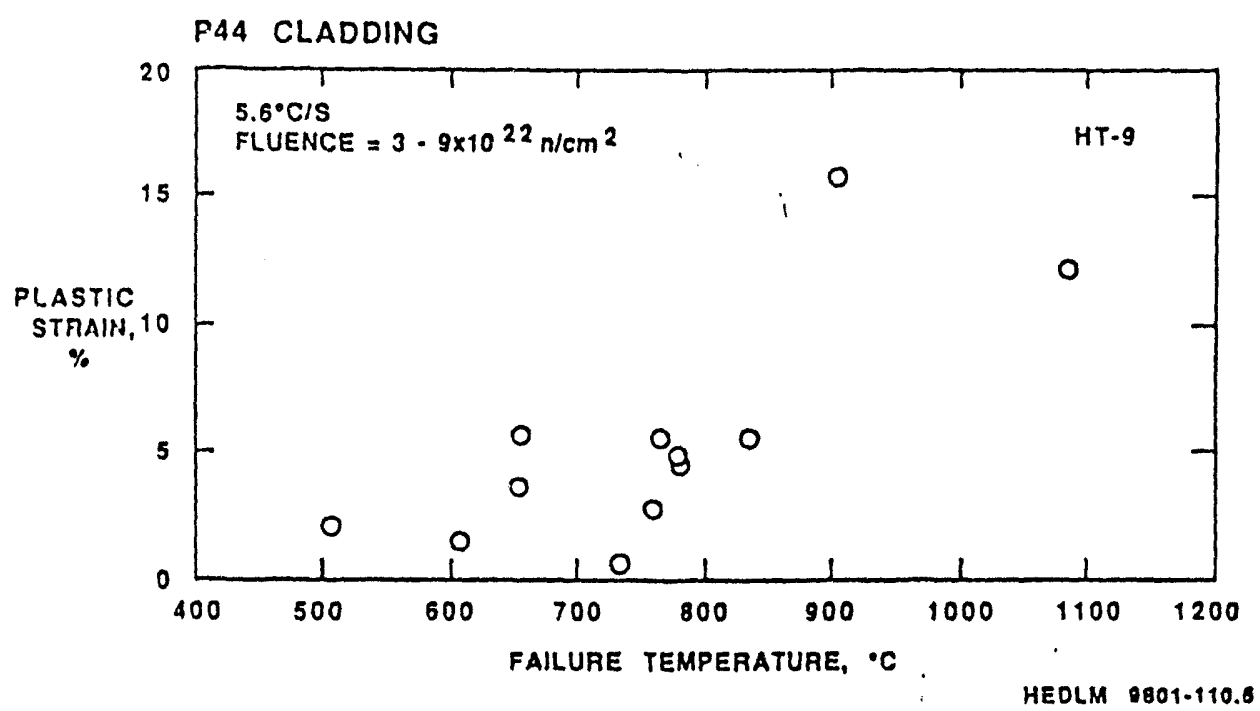

Figure 9 Strain of irradiated HTS cladding tested at $5.6^{\circ} \mathrm{C} / \mathrm{sec}$.

\section{REFERENCES}

1. R. J. Puigh, "In-reactor stress rupture data from MOTA after peak fluence of $17 \times 10^{22} \mathrm{n} / \mathrm{cm}^{2}$," private communication, Westinghouse Hanford Company, Richland, Washington, 1985.

2. C. W. Hunter, R. L. Fish, and J. J. Holmes, "Mechanical properties of unirradiated fast reactor cladding during simulated overpower transients," Nuclear Technology 27, 376-388 (1975).

3. J. L. Straalsund, R. L. Fish, and G. D. Johnson, "Correlation of Transient Test Data," Nuclear Technology 25, 531 (1975).

4. N. S. Cannon, F. H. Huang, and M. L. Hamilton, "Simulated transient behavior of HT9 cladding," ASTM STP 1046, 729-738 (1990). 


\section{DISTRIBUTION}

Number of Copies

ONSITE

3

Westinghouse Hanford Company

$$
\begin{aligned}
& \text { F. F. Huang } \\
& \text { Central Files } \\
& \text { Document Processing } \\
& \text { and Distribution } \\
& \text { Information Release } \\
& \text { Administration }
\end{aligned}
$$

G2-02

1.8-04

L8-15

H4-17 

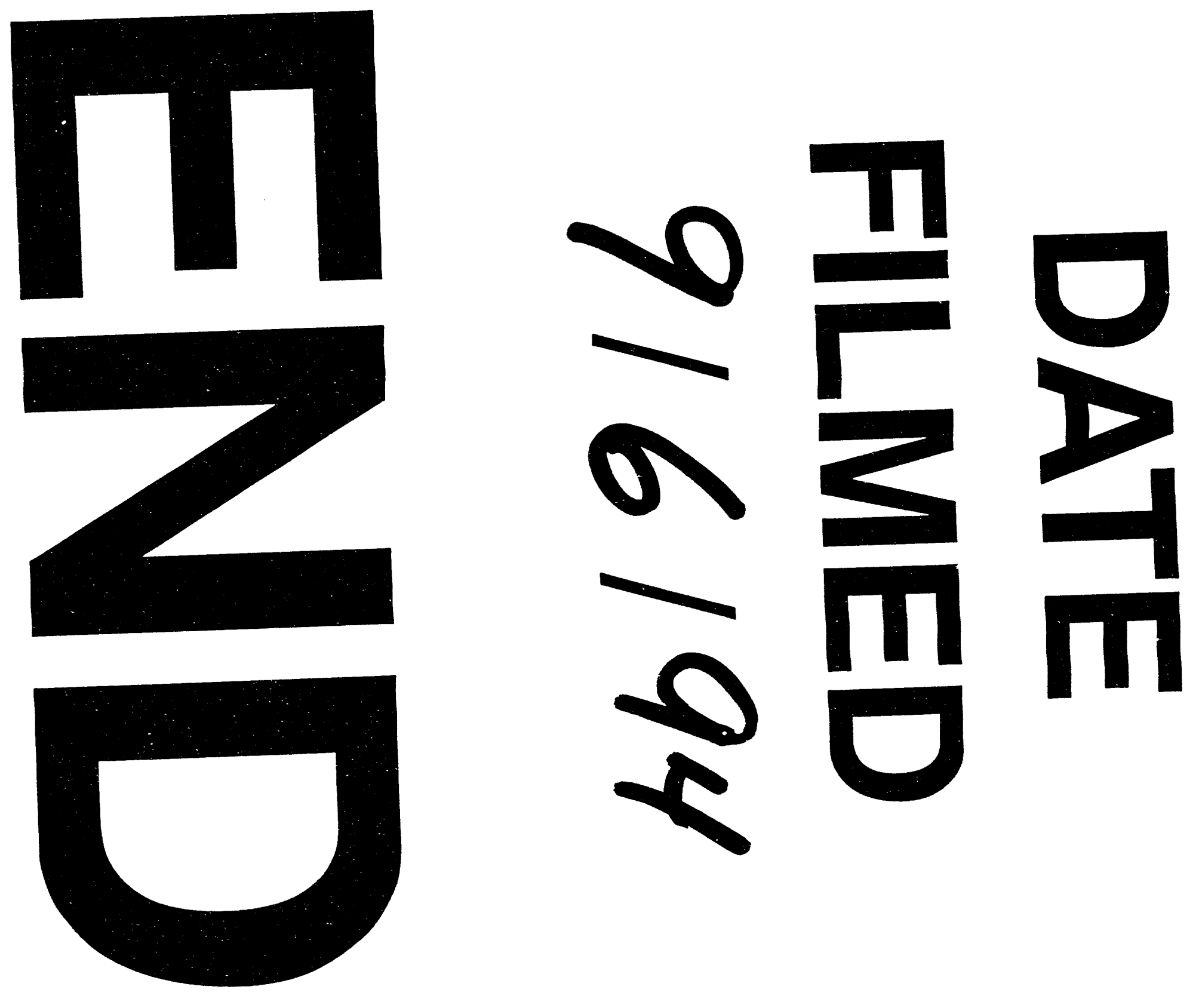
